\title{
REVIEW: PERAN MIKROBIOLOGI PADA INDUSTRI MAKANAN
}

\author{
Eni Sulastri ${ }^{1}$, Cecilia Indriani ${ }^{2}$, Muhammad Zainudin $^{3}$, Sri Wardhani ${ }^{4}$, \\ Meli Astriani ${ }^{5}$, Eko Ariyanto ${ }^{6 *}$ \\ 1,2,3,4,5 Program Studi Magister Pendidikan Biologi, Program Pascasarjana, \\ Universitas Muhammadiyah Palembang, Jalan A. Yani 13 Ulu Palembang 30263 \\ ${ }^{6}$ Program Studi Teknik Kimia, Fakultas Teknik, Universitas Muhammadiyah Palembang, \\ Jalan A. Yani 13 Ulu Palembang, Indonesia-30263 \\ *email: eko_ariyanto@um-palembang.ac.id
}

\begin{abstract}
According to the literature review, it was found that microorganisms in food do not only depend on the physical characteristics and food nutrition, but also series of affecting factors, such as temperature, $\mathrm{pH}$, water activity, and redox potential, considered as the most important factors driving the fate of microbes in food. Fermentation is a method of preserving food from raw materials with the help of microorganisms. Food processed through a fermentation process can be divided into four types: lactic acid fermentation, fungal fermentation, alcoholic fermentation, and high salt content fermentation. Nanotechnology has the potential benefits of nanomaterials in the food industry system, covering many aspects, such as food safety, packaging materials, nano-sensors, nutrient delivery systems, bioavailability, new materials for pathogen detection, and others.
\end{abstract}

Keywords: Microorganism, Microbe, Food

\begin{abstract}
ABSTRAK
Berdasarkan kajian literatur diketahui bahwa mikroorganisme dalam makanan tidak hanya bergantung pada karakteristik fisik dan nutrisi makanan tetapi juga pada serangkaian faktor yang mempengaruhi seperti suhu, $\mathrm{pH}$, aktivitas air, dan potensi redoks, dapat dianggap sebagai faktor terpenting yang mendorong nasib mikroba dalam makanan. Fermentasi merupakan cara pengawetan bahan pangan dari bahan mentah dengan bantuan mikroorganisme. Makanan diolah melalui proses fermentasi dibagi menjadi empat macam dilihat dari prosesnya yaitu fermentasi asam laktat, fermentasi jamur, fermentasi alcohol dan fermentasi dengan menggunakan kadar garam tinggi. Nanoteknologi memiliki manfaat potensial dari nanomaterial dalam sistem industri pangan, mencakup banyak aspek, seperti keamanan pangan, bahan pengemas, sensor nano, sistem pengiriman nutrisi, ketersediaan hayati, bahan baru untuk deteksi patogen dan lain-lain.
\end{abstract}

Kata Kunci: Microorganisme, Mikroba, Makanan

\section{PENDAHULUAN}

Seiring kemajuan teknologi dan ilmu pengetahuan mengenai industri makanan di Indonesia, sehingga saat ini bermunculan makanan yang bernilai gizi tinggi hasil fermentasi dari mikroorganisme, Selain proses pengolahan bahan mentah tersebut 
menjadi bahan jadi maupun setangah jadi, hal ini juga dapat menunda waktu pembusukan makanan. Proses ini melibatkan enzim baik yang dikelola secara tradisional maupun menggunakan teknologi canggih. Banyaknya manfaat yang diperoleh melalui proses pengolahan makanan dengan cara ini mendorong serta meningkatkan kesadaran masyarakat untuk mengkonsumsi makanan sehat fungsional yaitu jenis makanan yang mengandung komponen aktif yang menyehatkan. Makanan tersebut merupakan makanan hasil dari fermentasi mikroorganisme yaitu dengan bantuan bakteri maupun jamur. Jadi tidak semua mikrooragnisme dapat merugikan, salah satunya berperan dalam meningkatkan mutu pangan, untuk pembuatan obat-obatan, dan produk yang memiliki nilai tinggi. Contohnya Bakteri Lactobacili berperan dalam menghasilkan laktat seperti pembuatan yogurt, fermentasi sayuran, pembuatan roti dll selain itu terdapat Streptococcus, Sacchamyces cerevisiae juga punya penting dalam pembuatan kue. Selain bakteri jamur juga memiliki fungsi dalam industry makanan (Kumar A, 2016).

$$
\text { Pengolahan makanan melaui }
$$

fermentasi memiliki banyak teknik. Teknik yang dipakai harus memperhatikan bahan yang dipakai serta produk akhirnya dan pengolahannya pun harus memperhatikan suhu. Pengolahan dapat dilakukan pada suhu lingkungan, dapat juga memerlukan panas maupun mengolah dengan menghilangkan panas (Caplice and Fitzgerald, 1999). Mikroorganisme yang digunakan dalam pengolahan bahan pangan juga memerlukan proses yang higienis untuk menghindari kerusakan dan pembusukan bahan makanan tersebut karena akan memperpendek umur simpan. Pengolahan yang sembarangan akan menumbuhkan organisme pathogen yang dapat menyebakan penyakit apabila dikonsumsi.

\begin{abstract}
Sanitasi yang baik serta kehigienisan menjadi syarat untuk menghindari terjadinya cemaran mikroorganisme selama proses pengolahan pangan (Sengun and Karabiyikli, 2011). Mikroorganisme dalam makanan tidak hanya bergantung pada karakteristik fisik dan nutrisi makanan tetapi juga pada serangkaian faktor ekstrinsik dan intrinsik makanan dan interaksinya.
\end{abstract}

\section{HASIL DAN PEMBAHASAN}

\section{Faktor Yang Mempengaruhi Perilaku Mikroba dalam Makanan}

Mikroorganisme dalam makanan tidak hanya bergantung pada karakteristik fisik dan nutrisi makanan tetapi juga pada serangkaian faktor ekstrinsik dan intrinsik makanan dan interaksinya. Faktor-faktor, seperti suhu, $\mathrm{pH}$, aktivitas air, dan potensi redoks, dapat dianggap sebagai faktor terpenting yang mendorong nasib mikroba dalam makanan.

\section{Suhu}

Suhu merupakan factor yang menentukan di antara faktor-faktor yang mempengaruhi perilaku mikroba dalam makanan. Mikroorganisme berdasarkan suhu yang dibutuhkan untuk pertumbuhan, diklasifikasikan menjadi tiga kelompok yaitu psikrotrof tumbuh dengan baik pada $7^{0} \mathrm{C}$ atau lebih rendah dan memiliki kisaran suhu pertumbuhan optimal $20^{\circ}-30^{\circ} \mathrm{C}$; mesofil tumbuh dengan baik antara 20 dan $45^{\circ} \mathrm{C}$ dan memiliki kisaran suhu pertumbuhan optimal $30-40^{\circ} \mathrm{C}$; dan thermophiles tumbuh dengan baik pada usia 45 tahun atau lebih tinggi dan memiliki kisaran suhu pertumbuhan optimal $55-65^{0} \mathrm{C}$ (Jay, 1998). 
Mikroorganisme mesofilik sebagian besar adalah patogen kecuali Listeria monocytogenes, Yersinia enterocolitica, dan Clostridium botulinum tipe E, yang memiliki perilaku psikrofilik. Sedangkan mikroorganisme termofilik yang berperan penting pada industry makanan dan minuman adalah Alicyclobacillys, stearothermophilus, dan Bacillus sporothermodurans (Húngaro et al., 2014).

$$
\text { Penyimpanan makanan }
$$

menggunakan suhu rendah adalah salah satu cara terpenting untuk memperlambat aktivitas metabolisme (Beales, 2004; Mortlock et al., 1999). Mikroorganisme yang tumbuh pada suhu rendah mengubah komposisi asam lemak dari fosfolipid dan glikolipidnya untuk mengoptimalkan membran fluidity. Hal ini diperlukan agar nutrisi terus melewati membran dan untuk respirasi sel. penurunan suhu juga dapat berperan dalam memperpanjang umur simpan makanan. Temperatur rendah akan menghambat perkembangan mesofil dan termofil, tetapi tidak dari psikrotrof. Pertumbuhan mikroorganisme psikrotrofik dapat dihambat dengan menyesuaikan parameter ekstrinsik dan intrinsik lainnya (Beales, 2004).

\section{pH}

Sebagian besar mikroorganisme tumbuh dengan baik pada $\mathrm{pH}$ mendekati 7,0, meskipun beberapa dapat tumbuh pada nilai $\mathrm{pH}$ di bawah 4,0. Bakteri cenderung lebih sensitif terhadap $\mathrm{pH}$ daripada jamur dan ragi, dan bakteri patogen bahkan lebih sensitif. Mikroorganisme pembusuk dari kelompok bakteri asam laktat (BAL), misalnya, dapat tumbuh pada nilai $\mathrm{pH}$ serendah 2. Mikroorganisme patogen, seperti botulinum, tidak akan tumbuh pada nilai $\mathrm{pH}$ di bawah 4,6 karena potensi patogennya (Húngaro et al., 2014).

$\mathrm{pH}$ memiliki arti penting dalam intensitas pemprosesan termal, dengan makanan asam rendah dan tinggi diproses di atas dan di bawah $100^{\circ} \mathrm{C}$, masing-masing. Nilai $\mathrm{pH}$ minimum dan maksimum yang dapat ditoleransi oleh setiap spesies mikroba juga bergantung pada factor lain. Misalnya, $\mathrm{pH}$ minimum yang diperlukan untuk pertumbuhan laktobasilus tertentu bergantung pada jenis asam yang digunakan contohnya Asam sitrat, hidroklorat, fosfat, dan tartarat memungkinkan pertumbuhan pada nilai $\mathrm{pH}$ yang lebih rendah daripada asam asetat dan laktat. Konsentrasi minimum asam atau pengawet digunakan untuk menghambat mikroorganisme (Jay, 1998).

Setiap mikroorganisme memiliki kisaran $\mathrm{pH}$ yang optimal untuk kelangsungan hidup mereka. Setiap perubahan $\mathrm{pH}$ akan mempengaruhi hidup mikroorganisme tersebut karena sel mempunyai kemampuan untuk tumbuh yang bergantung pada kemampuan mikroorganisme dalam mengubah $\mathrm{pH}$ lingkungan untuk mencapai kisaran optimal mereka tumbuh (Jay, 1998).

\section{Aktivitas air}

Aktivitas air berkaitan dengan jumlah air yang tersedia pada reaksi metabolisme di dalam sel. Secara umum, bakteri membutuhkan air yang lebih tinggi daripada jamur, bakteri Gram-negatif membutuhkan aktivitas air yang lebih tinggi daripada bakteri 
Gram-positif. Kebanyakan bakteri terkait dengan pembusukan makanan yang dapat tumbuh di sebuah w di atas 0,91 , sedangkan sebagian besar jamur dapat tumbuh di sebuah w dibawah 0,80. Staphylococcus aureus bisa tumbuh di sebuah w dari 0,86 , sedangkan Botulinum kebutuhan w setidaknya 0,94 (Kumar A, 2016).

Ragi dapat menahan $\mathrm{pH}$ lebih rendah dari bakteri, dan hal yang sama berlaku untuk aktivitas air. Aktivitas air terendah yang dibutuhkan oleh suatu bakteri adalah 0,75 (bakteri halofilik), sedangkan kapang xerofilik dan ragi osmofilik dapat tumbuh pada $\mathrm{w}$ masing-masing 0,65 dan 0,61 (Lasztity, 1978). Efek umum mengurangi air di bawah nilai optimal adalah untuk meningkatkan fase lag dan mengurangi laju pertumbuhan. Menurunkan aktivitas air menyebabkan stres osmotik. Sebagian besar mikroorganisme telah berevolusi untuk berfungsi hanya dalam rentang aktivitas air tertentu (McMeekin and Ross, 2002). Aktivitas air di luar kisaran optimal dapat mengurangi fungsi metabolisme esensial sel dan menghambat sebagian besar proses fisiologis, seperti penyerapan nutrisi (McDonald and Sun, 1999) dan replikasi asam deoksiribonukleat (Meury, 1988).

\section{Faktor Lain}

Aktivitas air dan $\mathrm{pH}$ saling berinteraksi dengan suhu, karena mikroorganisme atau kelompok individu tumbuh dalam berbagai kondisi penyimpanan. Selain suhu, $\mathrm{pH}$, dan aktivitas air, faktor lain juga penting, seperti potensi redoks (Eh), sistem pengemasan, struktur makanan, kelembaban relatif, dan komposisi atmosfer. Beberapa bakteri anaerob seperti yang berasal dari genus Clostridium membutuhkan lingkungan dengan Eh yang berkurang untuk tumbuh (Eh 1/4 $200 \mathrm{mV}$ ), sedangkan yang dari genus Basil membutuhkan Eh positif untuk tumbuh. Bakteri yang tumbuh lebih baik dalam kondisi Eh yang sedikit berkurang disebut mikroaerofil, yang mencakup beberapa BAL, seperti Lactobacillus (Jay, 1998).

Gas di lingkungan seperti oksigen dan karbondioksida dapat mencegah atau mendorong petumbuhan mikroba. Oksigen dapat mencegah pertumbuhan organisme anaerob dalam makanan kemasan tetapi apabila konsentrasi oksigen terlalu tinggi maka akan meningkatkan kecepatan reaksi oksidasi yang dapat membuat pertumbuhan mikroorganisme aerob menjadi lebih cepat. Sedangkan gas karbondioksida memiliki sifat sebagai antimikroba (Mir et al., 2016).

\section{Peranan Mikrobiologi Pada Industri Makanan}

\section{Bioteknologi Tradisional Berbasis Fermentasi}

Fermentasi merupakan cara pengawetan bahan pangan dari bahan mentah dengan bantuan mikroorganisme. Proses ini juga dapat mengubah rasa, aroma dan tekstur pada makanan. Proses pengolahan bahan mentah melalui proses ini dapat meningkatkan kualitas makanan yang memiliki nilai gizi tinggi serta memudahkan proses pencernaan dalam tubuh.

Makanan diolah melalui proses fermentasi dibagi menjadi empat macam 
dilihat dari prosesnya yaitu fermentasi asam laktat, fermentasi jamur, fermentasi alkohol dan fermentasi dengan menggunakan kadar garam tinggi (Faridah and Sari, 2019).

1) Fermentasi oleh jamur contohnya dalam proses pembuatan tempe dengan bahan baku kedelai menggunakan mikroorganisme seperti Rhizopus oligosporus, Oncom dengan bantuan jamur Neurospora sitophila, Neurospora crassa dan Monilia sitophila.

2) Fermentasi menggunakan kadar garam tinggi contohnya pembuatan kecap dengan bahan baku kedelai dibantu oleh Aspergillus oryzae dan Aspergillus wentii.

3) Fermentasi asam laktat contohnya yoghurt dengan bahan baku susu dibantu oleh bakteri Lactobacillus Bulgaricus dan Streptococcus thermophilus. Serta pembuatan keju menggunakan bahan baku susu dibantu oleh jamur Penicillium camemmberti dan Penicillium roqueforti.

4) Fermentasi alkohol contohnya pembuatan roti dengan bahan tepung berbantu jamur Saccharomyces cerevisiae, pembuatan brem dari bahan nasi ketan dibantu oleh Aspergillus oryzae dan Saccharomyces cerevisiae

Ada juga beberapa mikroorganisme yang digunakan untuk bahan makanan sebagai Protein Sel Tunggal (PST), seperti: Spirulina (Alga Biru), Chlorella (Alga Hijau), Candida utilis (Fungi), Cellulomonas (Bakeri), Trichoderma sp (Yuniastri et al., 2018)

\section{Peran Nanoteknologi Dalam Industri Makanan}

Meskipun nanoteknologi dalam
industri makanan baru mulai
dieksplorasi dibandingkan dengan
beberapa bidang lainnya, namun
teknologi ini menunjukkan potensi
yang besar. Manfaat potensial dari
nanomaterial dalam sistem industri
pangan, mencakup banyak aspek,

seperti keamanan pangan, bahan pengemas, sensor nano, sistem pengiriman nutrisi, ketersediaan hayati, bahan baru untuk deteksi patogen dan lain-lain (Durán and Marcato, 2013).

Salah satu masalah dalam makanan adalah fisiknya, stabilitas kimia dan kontaminasi mikroba selama penyimpanan. Protein, lipid, karbohidrat, dan air dalam makanan berubah seiring waktu karena kondisi lingkungan dan pemrosesan (cahaya, kelembapan, dan suhu). Untuk melindungi makanan dari patogen yaitu dengan menggunakan kemasan atau film yang dapat dimakan dengan bahan antimikroba (Van Houdt and Michiels, 2010). Penggunaan film atau kemasan tipis yang dapat dimakan dapat menunda kerusakan makanan dengan meningkatkan umur simpan dan meningkatkan kualitas (Durán and Marcato, 2013).

Karagenan, kitosan, gelatin, asam polilaktat, asam poliglikolat, alginat, campuran pati dan natrium kaseinat adalah beberapa bahan yang digunakan dalam produksi bioplastik dengan aplikasi dalam kemasan film tipis yang dapat dimakan. Film tipis yang dapat dimakan dapat digunakan dalam aplikasi yang diperpanjang, misalnya, untuk melindungi buah, sayuran, daging, cokelat, permen, makanan yang dipanggang, dan kentang goreng, karena film ini bertindak sebagai kemasan aktif yang meningkatkan perlindungan penghalang dengan mencegah gas seperti oksigen dan etilen dari merusak kandungan makanan dan menjaga penampilan produk (Guzel-Seydim et al., 2004). 
Sebuah tinjauan penting pada film yang dapat dimakan dan pelapis pada produk makanan melaporkan bahwa produk ini memainkan peran penting dalam konservasi, distribusi dan pemasaran banyak agrofoods (Falguera et al., 2011). Film tipis yang dapat dimakan juga dapat dibuat dari nanolaminasi yang dapat dimakan yang mungkin melindungi makanan dari kelembaban, lipid, gas, aroma, dan bau. Bahan-bahan ini dapat dibuat dengan polisakarida, protein atau lipid.

$$
\text { Bayer Polymers telah }
$$
mengembangkan film kemasan Durethan KU22601, yang dikenal sebagai 'sistem hybrid' yang diperkaya dengan sejumlah besar nanopartikel silikat. Partikel-partikel ini mengurangi masuknya oksigen dan gas lainnya, dan keluarnya uap air, sehingga mencegah makanan dari pembusukan. Produk ini lebih kuat dan lebih tahan panas dibandingkan yang saat ini ada di pasaran. Lapisan silikat adalah struktur nano lain yang digunakan di area pengemasan. Penambahan struktur nano ini dalam matriks polimer meningkatkan sifat penghalang polimer, dan mereka mampu mengontrol laju pergeseran melalui jalur berliku-liku mereka. Silikat kompleks stabil (montmorillonite, hectorite dan saponite) ditambahkan ke polimer Zein, meningkatkan kekuatan, ketahanan dan permeabilitas air dan gas (Durán and Marcato, 2013).

Aplikasi nanokomposit lainnya adalah produksi kemasan antimikroba yang dapat meningkatkan umur simpan pangan. Nanokomposit ini disiapkan dengan polimer yang menggabungkan struktur nano seperti nanopartikel perak. Karena sifat antimikroba nanopartikel perak, partikel ini telah digunakan dalam produksi kemasan untuk mencegah pertumbuhan patogen pada produk segar atau daging. Nanopartikel perak dapat diproduksi melalui proses ramah lingkungan oleh jamur tanpa pelarut organik dan diaplikasikan, misalnya dalam kemasan sebagai antibakteri dan antijamur (Durán and Marcato, 2013).

Bahan kemasan berbahan dasar nanokomposit dari campuran polietilen dengan nanopartikel perak, nano- $\mathrm{TiO}_{2}$ dan teh hijau yang dilindungi tanah liat attapulgite untuk jangka waktu penyimpanan yang lama (Shi et al., 2008). Strategi lain untuk meningkatkan umur simpan makanan adalah produksi kemasan nano berdasarkan film polivinil klorida dengan bubuk nano-ZnO. Paket ini digunakan untuk konservasi apel, menghasilkan penurunan aktivitas polifenol oksidase dan pyrogallol peroksidase dan menghindari degradasi buah (Durán and Marcato, 2013).

\section{KESIMPULAN}

Mikroorganisme dalam makanan tidak hanya bergantung pada karakteristik fisik dan nutrisi makanan tetapi juga pada serangkaian faktor yang mempengaruhi seperti suhu, $\mathrm{pH}$, aktivitas air, dan potensi redoks, dapat dianggap sebagai faktor terpenting yang mendorong nasib mikroba dalam makanan. Fermentasi merupakan cara pengawetan bahan pangan dari bahan mentah dengan bantuan mikroorganisme. Makanan diolah melalui proses fermentasi dibagi menjadi empat macam dilihat dari prosesnya yaitu fermentasi asam laktat, fermentasi jamur, fermentasi alcohol dan fermentasi dengan menggunakan kadar garam tinggi.

Nanoteknologi memiliki manfaat potensial dari nanomaterial dalam sistem industri pangan, mencakup banyak aspek, seperti keamanan pangan, bahan 
pengemas, sensor nano, sistem pengiriman nutrisi, ketersediaan hayati, bahan baru untuk deteksi patogen dan lain-lain

\section{DAFTAR PUSTAKA}

Beales, N., 2004, Adaptation of Microorganisms to Cold Temperatures, Weak Acid Preservatives, Low pH, and Osmotic Stress: A Review, Compr. Rev. Food Sci. Food Saf., 3 (1), 1-20.

Caplice, E. and Fitzgerald, G.F., 1999, Food fermentations: Role of microorganisms in food production and preservation, Int. J. Food Microbiol., 50 (1-2), 131-149.

Durán, N. and Marcato, P.D., 2013, Nanobiotechnology perspectives. Role of nanotechnology in the food industry: A review, Int. J. Food Sci. Technol., 48 (6), 1127-1134.

Falguera, V., Quintero, J.P., Jiménez, A., Muñoz, J.A. and Ibarz, A., 2011, Edible films and coatings: Structures, active functions and trends in their use, Trends Food Sci. Technol., 22 (6), 292-303.

Faridah, H.D. and Sari, S.K., 2019, Utilization of Microorganism on the Development of Halal Food Based on Biotechnology, J. Halal Prod. Res., 2 (1), 33.

Guzel-Seydim, Z.B., Greene, A.K. and Seydim, A.C., 2004, Use of ozone in the food industry, LWT - Food Sci. Technol., 37 (4), 453-460.

Van Houdt, R. and Michiels, C.W., 2010, Biofilm formation and the food industry, a focus on the bacterial outer surface, J. Appl. Microbiol., 109 (4), 1117-1131.

Húngaro, H.M., Peña, W.E.L., Silva, N.B.M., Carvalho, R. V., Alvarenga, V.O. and Sant'Ana, A.S., 2014,
Food Microbiology, Encycl. Agric. Food Syst., Vol. 3, pp. 213-231.

Jay, J.M., 1998, Modern Food Microbiology, 5th ed., Aspen Publishers, Inc.

Kumar A., 2016, Role of Microbes in Food and Industrial Microbiology, J. Food Ind. Microbiol., 02 (02), 1011.

Lasztity, R., 1978, Microorganisms Important in Food Microbiology., Food Microbiol., Vol. III, Encyclopedia of Life Support Systems (EOLSS), p. 539.

McDonald, K. and Sun, D.W., 1999, Predictive food microbiology for the meat industry: A review, Int. J. Food Microbiol., 52 (1-2), 1-27.

McMeekin, T.A. and Ross, T., 2002, Predictive microbiology: Providing a knowledge-based framework for change management, Int. J. Food Microbiol., 78 (1-2), 133-153.

Meury, J., 1988, Glycine betaine reverses the effects of osmotic stress on DNA replication and cellular division in Escherichia coli, Arch Microbiol, 3 (149), 232-239.

Mir, S.A., Shah, M.A. and Mir, M.M., 2016, Understanding the Role of Plasma Technology in Food Industry, Food Bioprocess Technol., 9 (5), 734-750.

Mortlock, M.P., Peters, A.C. and Griffith, C.J., 1999, Food hygiene and hazard analysis critical control point in United Kingdom food industry: Practices, perceptions, and attitudes, J. Food Prot., 62 (7), 786-792.

Sengun, I.Y. and Karabiyikli, S., 2011, Importance of acetic acid bacteria in food industry, Food Control, Elsevier Ltd, 22 (5), 647-656.

Shi, L., Zhao, Y., Zhang, X., Su, H. and Tan, T., 2008, Antibacterial and 
Review: Peran Mikrobiologi.., Eni Sulastri, Cecilia Indriani, Muhammad Zainudin, Sri Wardhani, Meli Astriani, Eko Ariyanto.., .Indobiosains, Volume 4 No. 1, Februari 2022, 1-8.

anti-mildew behavior of chitosan/nano-TiO2 composite emulsion, Korean J. Chem. Eng., 25 (6), 1434-1438.

Yuniastri, R., Ismawati, I. and Putri, R.D., 2018, Mikroorganisme Dalam Pangan, J. Pertan. Cemara, 15 (2), 15-20. 